\title{
Analisis Usability Aplikasi iBadung Menggunakan Heuristic Evaluation Method
}

\author{
I Gusti Ayu Agung Diah Indrayani, I Putu Agung Bayupati, I Made Suwija Putra \\ Program Studi Teknologi Informasi, Fakultas Teknik, Universitas Udayana, Bukit \\ Jimbaran, Bali, Indonesia,Telp. (0361) 701806 \\ e-mail: diahindrayani21@gmail.com, bayupati@it.unud.ac.id, putrasuwija@unud.ac.id
}

\begin{abstract}
Abstrak
Seiring berjalannya waktu teknologi terus berkembang semakin canggih. Dimulai dari website, sampai dengan teknologi mobile. Teknologi website dan mobile memiliki peran yang sangat penting sebagai sumber informasi. iBadung merupakan sebuah aplikasi mobile yang memiliki fungsi sebagai wadah yang menyediakan berbagai jenis buku bacaan atau dapat disebut perpustakaan digital yang dapat diakses oleh semua orang. Untuk dapat mengukur tingkat kenyamanan user, kelayakan aplikasi, dan interface aplikasi maka dilakukan pengujian usability, tujuan untuk menganalisis user experience dalam penggunaan aplikasi iBadung. Fungsi dari metode Heuristic Evaluation adalah mengetahui tingkat usability pada iBadung. Pengujian ini mengisi kuesioner dilakukan oleh 17 orang responden dengan kategori pengguna awam, pengguna biasa dan pengguna administrator. Hasil yang didapat dari pengujian pertama pengguna awam mendapat nilai severity rating skala 2 kategori minor usability problem, pengguna biasa dan pengguna administrator mendapat nilai severity rating skala 1 kategori cosmetic problem. Temuan permasalahan yaitu pada logo aplikasi, tata letak icon menu, tampilan menu login, penambahan pop up exit pada tampilan aplikasi iBadung dan dilakukan perbaikan tampilan sesuai rekomendasi user selanjutnya melakukan pengujian kedua setelah perbaikan tampilan selesai dikerjakan.
\end{abstract}

Kata kunci: Teknologi mobile, Aplikasi iBadung, User Experience, Usability, Heuristic Evaluation

\begin{abstract}
As time goes by technology continues to develop increasingly sophisticated. Starting from the website, to mobile technology. Website and mobile technology have a very important role as a source of information. iBadung is a mobile application that has a function as a container that provides various types of reading books or can be called a digital library that can be accessed by everyone. To be able to measure the level of user comfort, application eligibility, and application interfaces, usability testing is performed, the purpose of analyzing user experience in the use of the iBadung application. The function of the Heuristic Evaluation method is to know the level of usability in iBadung. This test filled out the questionnaire conducted by 17 respondents in the category of ordinary users, ordinary users, and administrator users. The results obtained from the first test of ordinary users get a scale severity rating of 2 minor usability problem categories, ordinary users and administrator users get a scale severity rating of 1 in the cosmetic problem category. The finding of the problem is the application logo, the layout of the menu icon, the appearance of the login menu, the addition of exit pop-ups to the iBadung application display and the appearance of improvements according to the user's recommendations, then do a second test after the appearance of the repair is complete.
\end{abstract}

Keywords : Mobile Technology, iBadung Applications, User Experience, Usability, Heuristic Evaluation. 


\section{Pendahuluan}

Perkembangan teknologi setiap waktu terus berkembang. Seiring berjalannya waktu perkembangan internet semakin pesat sesuai kebutuhan pengguna.User experience memiliki peran penting dalam pengembangan suatu produk maupun sebuah sistem [1]. User experience atau seseorang yang memiliki peran dalam menggunakan produk dan sistem. Nilai dari produk atau sistem tersebut dapat diketahui dari user experience bagaimana tanggapan dari pengguna dalam menggunakan produk atau sistem tersebut. Mengetahui kelayakan ,tingkat kenyamanan dan kepuasan pengguna dari produk atau sistem yang digunakan dapat diketahui melalui user experience.

Di Indonesia banyak penelitian yang dilakukan berkaitan dengan user experience untuk menilai suatu produk, sistem, maupun jasa. Banyak objek yang menjadi bahan penelitian yang berkaitan dengan user experience. Salah satu contoh penelitian yaitu website dan aplikasi mobile yang ada di Indonesia yang dievaluasi berdasarkan user experience. Secara umum penelitian yang berkaitan dengan user experience yaitu untuk mengetahui permasalah atau kekurangan dari suatu produk, sistem, dan jasa. Permasalah yang terkait seperti user interface, eficiency, kegunaan, fungsi, dan kesenangan pengguna[2]. Perancangan suatu produk, dan sistem harus sesuai dengan keinginan pengguna, dapat digunakan dengan baik dan mudah[3].

Salah satu target dalam penelitian ini adalah aplikasi mobile iBadung yang merupakan Sebuah aplikasi perpustakaan digital yang berbasis mobile, dimana aplikasi ini berperan sebagai alat bantu mempermudah masyarakat ataupun pelajar untuk mengakses informasi mengenai pencarian buku maupun melakukan peminjaman buku secara online, tanpa harus pergi ke perpustakaan langsung. Dalam penggunaannya ditemukan beberapa user memberikan komentar terkait tampilan dan kenyamanan dalam menggunakan aplikasi. User mengeluhkan mengenai tampilan yang kurang menarik dan kurang dipahami seperti menu register, kategori buku. Diketahui pada instansi Pemerintahan Dinas Kearsipan dan Perpustakaan Kabupaten Badung yang mengelola aplikasi iBadung belum pernah dilakukan penelitian terkait usability. Maka dari itu untuk mengetahui bagaimana pengalaman pengguna serta mengukur kepuasan pengguna dalam menggunakan aplikasi iBadung bisa diketahui dengan melakukan pengujian Usability menggunakan metode Heuristic Evaluation[4]. Heuristic evaluation merupakan sebuah metode yang digunakan untuk mengidentifikasi masalah usability dalam hal user interface design[5]. Hasil pengujian ini menemukan permasalahan usability pada interface aplikasi ibadung dan mendapat rekomendasi untuk dilakukan perbaikan tampilan, setelah itu dilakukan konfirmasi tampilan yang telah diperbaiki tahap kedua kepada responden yang terlibat sebelumnya. Hasil akhir mendapatkan perbandingan nilai heuristic evaluation dari pengujian pertama dan pengujian kedua.

\section{Metodologi Penelitian}

Berikut merupakan gambaran alur proses dalam pengujian usability aplikasi iBadung berdasarkan metode Heuristic Evaluation. Alur penelitian merupakan tahapan-tahapan setiap proses yang akan dilakukan dalam penelitian. Gambaran alur penelitian dapat dilihat pada gambar 1 berikut. 


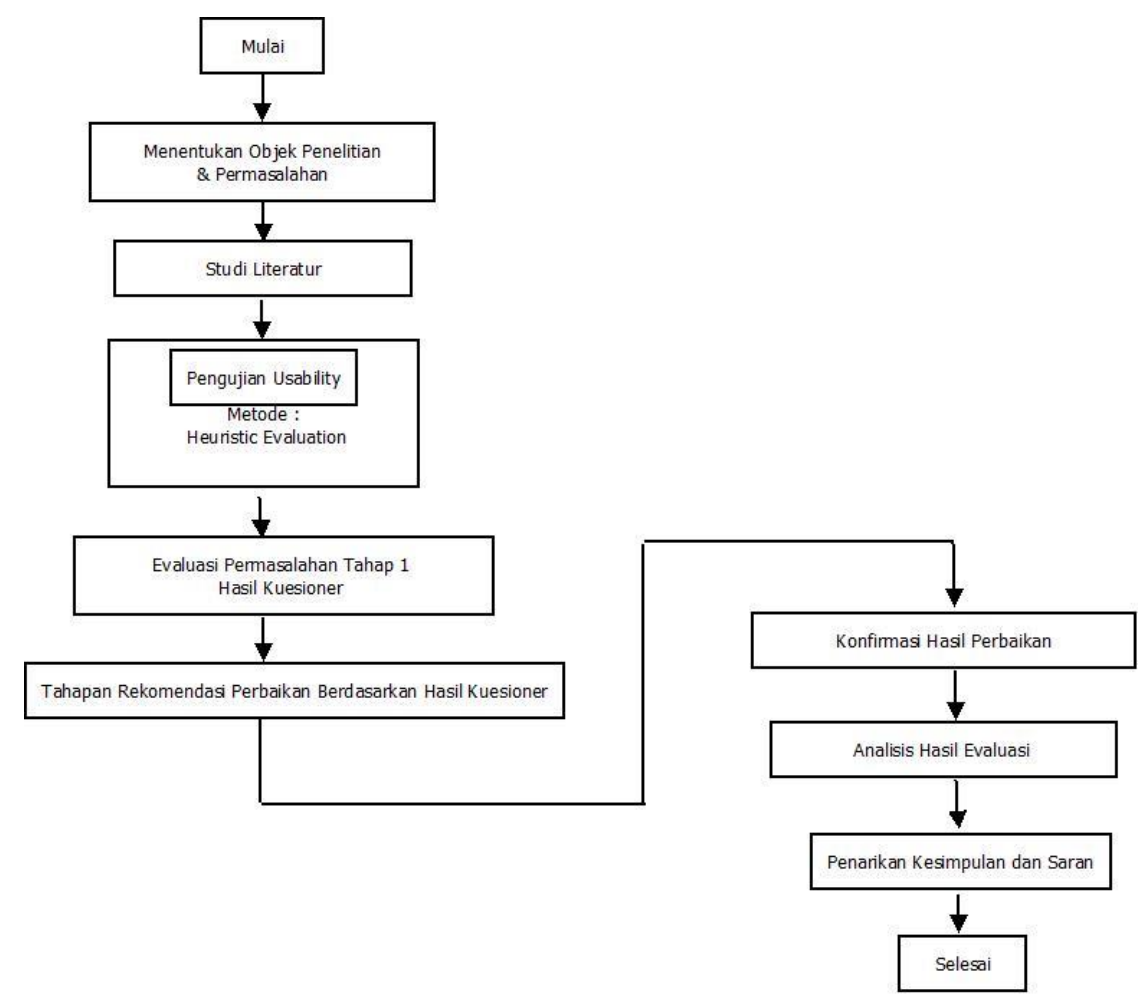

Gambar 1. Alur Penelitian

Tahapan pada alur penelitian dalam pengujian usability aplikasi iBadung menggunakan metode Heuristic Evalution terdapat 8 tahapan dalam melakukan proses penelitian yaitu pertama menentukan objek penelitan dan permasalah yang akan dibahas dalam penelitian. Tahap kedua yaitu melakukan studi literatur mempelajari teori dari jurnal, ebook, yang berkaitan dengan penelitian yang dibahas. Tahap ketiga melakukan pengujian usability pada aplikasi iBadung. Pengujian usability ini dilakukan dengan penyebaran kuesioner dengan metode Heuristic Evaluation. Tahap keempat Melakukan proses evaluasi usability aplikasi iBadung pada tahap pertama melakukan rekap data kuesioner dan diolah sesuai dengan metode Heuristic Evaluation. Setelah rekap data selesai dilakukan, akan mendapatkan hasil yang berupa adanya rekomendasi perbaikan aplikasi iBadung berdasarkan pengujian usability yang sudah dilakukan oleh responden. Tahapan kelima melakukan perbaikan design sesuai masalah yang ditemukan dalam pengujian usability oleh responden. Tahapan keenam konfirmasi hasil perbaikan yang telah dilakukan sesuai rekomendasi dari responden. Tahapan ketujuh evaluasi hasil pengujian tahap pertama dan kedua aplikasi iBadung menggunakan metode Heuristic Evaluation. Tahap kedelapan pengambilan kesimpulan setelah semua tahapan evaluasi selesai dilakukan. Saran yang diberikan ditujukan untuk memperbaiki dari kekurangan yang terdapat selama proses penelitian dan memberikan rekomendasi dalam perbaikan aplikasi baik dari segi fitur, tampilan, bahasa dan lainnya.

\section{Kajian Pustaka}

Berikut merupakan kajian pustaka yang terkait dengan penelitian usability bersumber dari jurnal, ebook, artikel.

\subsection{User Experience}

Peran User experience sangat penting dalam pengembangan suatu produk, jasa, ataupun sebuah sistem. User experience atau seseorang yang memiliki peran dalam menggunakan produk, jasa dan sistem. Nilai dari produk, jasa atau sistem tersebut dapat diketahui dari user experience bagaimana tanggapan dari pengguna dalam menggunakan produk, jasa atau sistem tersebut. Mengetahui kelayakan, tingkat kenyamanan dan kepuasan pengguna dari produk, jasa dan sistem yang digunakan dapat diketahui melalui user 
experience. Pencapaian berhasil atau kegagalan produk, jasa dan sistem dapat diketahui melalui user experience [6].

\subsection{User Interface}

User interface merupakan suatu komponen penting dalam perancangan sistem informasi yang melibatkan interaksi user untuk menghasilkan proses input serta output. User interface arti dalam bahasa Indonesia yaitu sebuah antarmuka aplikasi. User interface yang bagus adalah user interface yang dapat menyatukan sebuah interaksi user dengan penyedia informasi. Suatu aplikasi yang design interface nya menarik dan user friendly akan lebih mudah digunakan dan dimengerti oleh user [7]. Design interface berhubungan dengan tampilan layar pengguna, karena design yang baik adalah poin penting untuk membuat user tertarik mencoba dan menggunakan aplikasi tersebut [8]. Sebelum aplikasi diluncurkan perancangan user interface harus dibuat dengan konsep bagus dan sesuai kebutuhan user. Jika dalam perancangan tidak matang akan beresiko aplikasi bisa gagal setelah diluncurkan [9].

\subsection{Usability}

Definisi usability menurut ISO 9241:11 (1998) yaitu mengetahui tingkat nilai keberhasilan dalam pengembangan suatu bentuk produk yang dapat digunakan user untuk mencapai target sesuai diinginkan seperti aspek efektivitas, aspek efisiensi dan mencapai kepuasan user dalam hal tertentu. Usability digunakan untuk melakukan pengukuran tingkat kegunaan interface dari sebuah website maupun aplikasi mobile [10]. Meningkatkan kualitas interface dapat diketahui dengan pengujian usability [11].

\subsection{Heuristic Evaluation}

Pengujian usability aplikasi iBadung dengan metode Heuristic Evaluation dilakukan untuk evaluasi design interface dari aplikasi iBadung. Pengujian ini dilakukan berdasarkan 10 aspek menurut Nielsen (1994) [12]. Nilai severity rating berdasarkan Heuristic Evaluation dapat dilihat pada tabel 1 [11].

1. Visibility of system status yaitu suatu sistem dapat memberi tahu pengguna terhadap situasi yang sedang terjadi dari feed back yang diberikan.

2. Match between system and the real world yaitu suatu sistem perlu menggunakan konsep dan bahasa yang dengan mudah dimengerti oleh user.

3. User control and freedom yaitu pencegahan kesalahan yang mungkin dilakukan oleh user, dan sistem perlu membuat menu untuk undo atau redo.

4. Consistency and standard yaitu konsistensi antarmuka pada sistem sesuai standar

5. Error prevention yaitu penanggulangan kesalah yang dapat terjadi

6. Recognition rather than recall yaitu komponen pada sistem yang dibuat mudah supaya user tidak perlu mengingat-ingat proses berikutnya

7. Flexibility and efficiency of use yaitu suatu sistem yang bersifat efisien serta fleksibel membuat user cepat dalam melakukan tugas

8. Aesthetic and minimalist design yaitu desain yang aesthetic tidak mengganggu pengguna dalam menggunakan suatu sistem

9. Help users recognize, diagnose, and recover from errors yaitu pesan error dengan bahasa yang sederhana dan memberikan solusi kepada user

10. Help and documentation yaitu menyediakan fitur bantuan dan dokumentasi untuk membantu user dalam menggunakan sistem

Pengujian usability dilakukan dengan membuat kuesioner beberapa pertanyaan yang terkait dengan tampilan aplikasi iBadung disesuaikan dengan 10 aspek heuristic evaluation. Kemudian dilakukan pengujian kepada responden yang terlibat seperti pengguna awam yaitu responden yang belum pernah menggunakan aplikasi, pengguna biasa yaitu responden yang sudah pernah menggunakan aplikasi, dan pengguna administrator yaitu responden admin yang mengelola dashboard iBadung. Setelah pengujian usability selesai dilakukan, tahapan selanjutnya yaitu merekap kuesioner berdasarkan perhitungan metode heuristic evaluation.

Perhitungan pada evaluasi Heuristic evaluation menggunakan persamaan (1):

$\Sigma \mathrm{H} \chi=(0 * x)+(1 * x)+(2 * x)+(3 * x)+(4 * x)$

Dengan $\mathrm{\Sigma} H \chi$ jumlah skor rating dari sub aspek usability dalam setiap aspek usability

$\left(\mathrm{H}_{1}, \mathrm{H} 2, \ldots \ldots \ldots \mathrm{H1O}\right.$ ) 
$x=$ poin usability, bernilai $1 / 0$

Berikutnya untuk menghasilkan nilai severity rating dari masing-masing aspek usability menggunakan persamaan (2):

$s v=\sum \frac{H x}{n}$

Dengan,

$s v=$ Hasil severity rating dalam satu aspek usability

$n=$ Banyaknya sub aspek usability dalam setiap aspek usability

Tabel 1. Skala Nilai Severity Rating

\begin{tabular}{cl}
\hline Severity Rating & \multicolumn{1}{c}{ Keterangan } \\
\hline 0 & $\begin{array}{l}\text { Tidak ditemukan adanya permasalahan atau kekurangan pada } \\
\text { usability } \\
\text { Kategori cosmetic problem, permasalahan tidak perlu diperbaiki } \\
\text { kecuali waktu pengerjaan proyek masih tersedia. }\end{array}$ \\
2 & $\begin{array}{l}\text { Kategori minor usability problem, permasalahan kegunaan kecil, } \\
\text { perbaikan ini diberikan prioritas yang rendah. } \\
\text { Kategori major usability problem, permasalahan kegunaan utama, } \\
\text { perbaikan penting dilakukan, maka dari itu diberikan prioritas tinggi. } \\
\text { Kategori usability catastrophe, permasalahan perbaikan ini harus } \\
\text { dilakukan sebelum produk diluncurkan. }\end{array}$ \\
\end{tabular}

Tabel 1 merupakan nilai severity rating dalam pengujian usability berdasarkan metode Heuristic Evaluation. Nilai severity rating menunjukkan seberapa besar kategori permasalahan yang ditemukan.

\subsection{Dasar Rekomendasi Perbaikan}

Dasar melakukan rekomendasi perbaikan setelah pengujian usability dilakukan terkait rekomendasi perbaikan tampilan dari user yaitu berdasarkan teori Eight Golden Rules oleh Ben Sheiderman dan Chaterine Plaisant mengenai Delapan Aturan Emas dari desain antarmuka dalam bukunya yang berjudul Designing The User Interface sebagai berikut [13].

1. Strive for consistency aturan pertama ini adalah untuk mencapai atau bertujuan dalam mengatur konsistensi interface sebuah program.

2. Cater to universal usability aturan kedua adalah menyediakan tombol pintasan. Fungsi menggunakan tombol pintasan adalah untuk menghemat waktu atau meningkatkan kinerja untuk pengguna.

3. Offer informative feedback aturan ketiga adalah umpan balik sangat penting karena pengguna akan menerima pesan dari sistem untuk memberi tahu pengguna apa yang sedang terjadi.

4. Design dialogs to yield closure aturan keempat umpan balik diperlihatkan kepada pengguna untuk memberi tahu atau menunjukkan apa proses itu selesai atau akan ada proses selanjutnya.

5. Prevent errors aturan kelima tujuan dari aturan ini adalah untuk mencegah kesalahan terjadi dan memberikan penanganan kesalahan sederhana atau memulihkan ketika kesalahan terjadi.

6. Permit easy reversal of actions aturan keenam pengguna diberikan fitur undo yang dapat membatalkan semua tindakan yang telah dilakukan sehingga dapat kembali dari kesalahan.

7. Support internal locus of control aturan ketujuh ini adalah untuk memastikan bahwa pengguna adalah orang yang bertanggung jawab atas sistem tetapi bukan sistem yang mengendalikan. 
8. Reduce short-term memory load aturan kedelapan tampilan interface harus sederhana untuk mengurangi beban memori jangka pendek

\section{Hasil dan Pembahasan}

Hasil dari penelitian dalam pengujian usability pada aplikasi iBadung dengan metode Heuristic Evaluation dapat diketahui dari tabel dibawah ini.

\subsection{Hasil Pengujian Heuristic Evaluation Tahap Pertama}

Berikut merupakan hasil pengujian usability dengan metode heuristic evaluation melibatkan 17 responden dapat dilihat pada tabel dibawah ini.

Tabel 2. Hasil Pengujian Pengguna Awam

\begin{tabular}{lcc}
\hline \multicolumn{1}{c}{ Aspek } & Nilai Masing-masing Aspek & Nilai Pembulatan \\
\hline 1. Visibility of system status & 2.436 & 2 \\
2. Match between system and the & 1.800 & 2 \\
real world & 1.467 & 1 \\
3. User control and freedom & 1.660 & 2 \\
4. Consistency and standard & 1.740 & 2 \\
5. Error prevention & 1.460 & 1 \\
6. Recognition rather than recall & 1.267 & 1 \\
7. Flexibility and efficiency of use & 1.200 & 1 \\
8. Aesthetic and minimalist design & 1.114 & 1 \\
9. Help users recognize, & & \\
diagnose, and recover from errors & 1.180 & 1 \\
10. Help and documentation & 1.532 & 2 \\
Nilai Rata-rata Severity Rating & & \\
\hline
\end{tabular}

Tabel 2 merupakan hasil dari pengujian usability dengan metode Heuristic Evaluation dari responden pengguna awam. Responden pengguna awam merupakan responden yang masih awam dengan aplikasi iBadung, dan mendapatkan hasil nilai severity rating dari masingmasing aspek. Nilai rata-rata severity rating yang diperoleh yaitu 1.532 yang dibulatkan menjadi skala 2 minor usability problem, yang artinya perbaikan dengan prioritas rendah tetapi perbaikan tetap dapat dilakukan.

Tabel 3. Hasil Pengujian Pengguna Biasa

\begin{tabular}{lcc}
\hline \multicolumn{1}{c}{ Aspek } & Nilai Masing-masing Aspek & Nilai Pembulatan \\
\hline 1. Visibility of system status & 2.109 & 1 \\
2. Match between system and the & 1.475 & 1 \\
real world & 1.900 & 2 \\
3. User control and freedom & 1.420 & 1 \\
4. Consistency and standard & 1.400 & 1 \\
5. Error prevention & 0.880 & 1 \\
6. Recognition rather than recall & 1.133 & 1 \\
7. Flexibility and efficiency of use & 1.200 & 1 \\
8. Aesthetic and minimalist design & 1.714 & 2 \\
9. Help users recognize, & & \\
diagnose, and recover from errors & 1.600 & 2 \\
10. Help and documentation & 1.383 & 1 \\
Nilai Rata-rata Severity Rating & & \\
\hline
\end{tabular}

Tabel 3 merupakan hasil dari pengujian usability dengan metode Heuristic Evaluation dari responden pengguna biasa. Responden pengguna biasa merupakan responden yang sudah pernah menggunakan aplikasi iBadung, dan mendapatkan hasil nilai severity rating dari masing-masing aspek. Nilai rata-rata severity rating yang diperoleh yaitu 1.383 yang dibulatkan 
menjadi skala 1 , kategori cosmetic problem yang artinya perbaikan dapat dilakukan jika waktu pengerjaan proyek masih tersedia.

Tabel 4. Hasil Pengujian Pengguna Administrator

\begin{tabular}{lcc}
\hline \multicolumn{1}{c}{ Aspek } & $\begin{array}{c}\text { Nilai SR Masing-Masing } \\
\text { Aspek }\end{array}$ & $\begin{array}{c}\text { Nilai } \\
\text { Pembulatan }\end{array}$ \\
\hline 1. Visibility of system status & 0.2 & 0 \\
2. Match between system and the real & 0.3 & 0 \\
world & 0.0 & 0 \\
3. User control and freedom & 0.0 & 0 \\
4. Consistency and standard & 0.8 & 1 \\
5. Error prevention & 1.1 & 1 \\
6. Recognition rather than recall & 0.2 & 0 \\
7. Flexibility and efficiency of use & 0.0 & 0 \\
8. Aesthetic and minimalist design & 0.8 & 1 \\
9. Help users recognize, diagnose, and & & 2 \\
recover from errors & 2.0 & 1 \\
10. Help and documentation & 0.5 & \\
Nilai rata-rata severity rating & & \\
\hline
\end{tabular}

Tabel 4. merupakan hasil dari pengujian usability oleh administrator iBadung dengan metode Heuristic Evaluation dan mendapatkan hasil nilai severity rating dari masing-masing aspek. Nilai rata-rata severity rating yang diperoleh yaitu 0.5 yang dibulatkan menjadi skala 1 , kategori cosmetic problem yang artinya perbaikan dapat dilakukan jika waktu pengerjaan proyek masih tersedia.

\subsection{Hasil Rekomendasi Perbaikan}

Berdasarkan masukkan responden hasil dari kuesioner sesuai dengan metode Heuristic Evaluation yang mendapatkan rekomendasi perbaikan dari user experience dalam menggunakan aplikasi iBadung, telah dilakukan perbaikan tampilan berdasarkan referensi dari teori Eight Golden Rules oleh Ben Sheiderman dan Chaterine Plaisant.

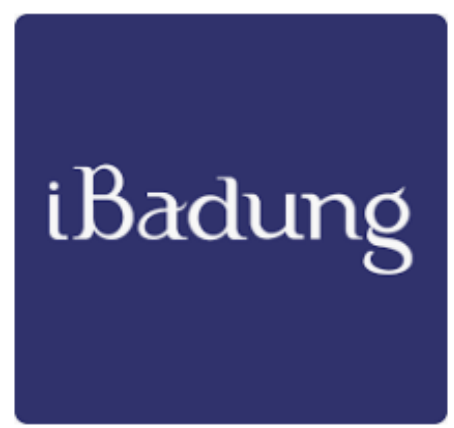

A

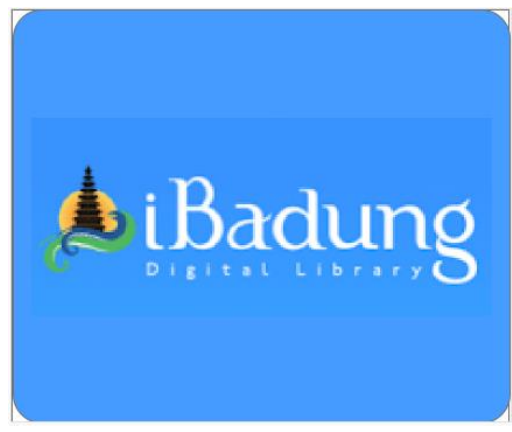

B

Gambar 2. Tampilan Logo Aplikasi iBadung

Gambar A merupakan tampilan logo aplikasi iBadung sebelum dilakukan tahapan perbaikan tampilan, sedangkan gambar B telah dilakukan perbaikan sesuai dengan rekomendasi user hasil dari kuesioner pada aspek visibility of system status yaitu tampilan logo kurang menarik dan nama aplikasi harus berhubungan dengan perpustakaan. Maka dibuatkan rekomendasi perbaikan tampilan baru dengan merubah warna tampilan menjadi lebih hidup menjadi warna biru muda dengan menambahkan keterangan Digital Library guna untuk lebih memperjelas mengenai aplikasi iBadung. 


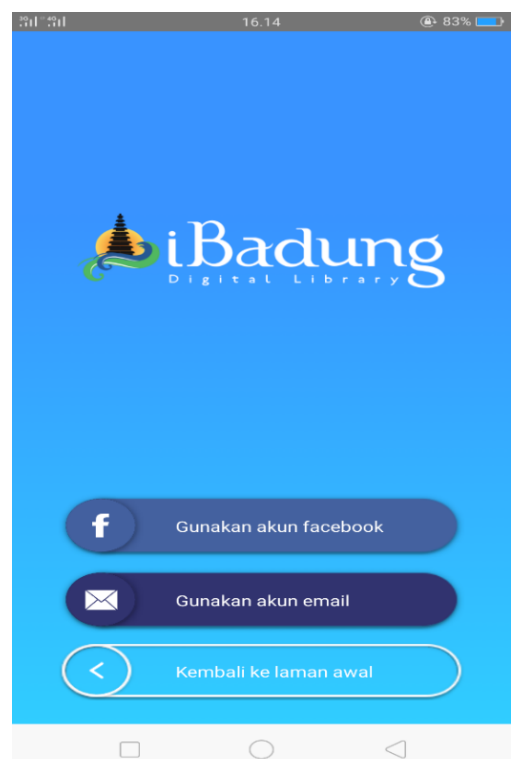

A

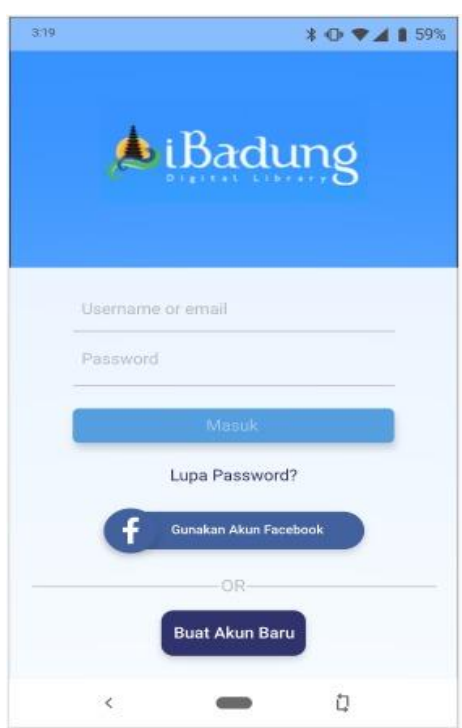

B

Gambar 3. Tampilan Login Aplikasi iBadung

Gambar A merupakan tampilan login aplikasi iBadung sebelum dilakukan tahapan perbaikan tampilan, sedangkan gambar B telah dilakukan perbaikan tampilan sesuai dengan rekomendasi user dari hasil kuesioner pada aspek visibility of system status yaitu tampilan menu login perlu diperbaiki karena kurang jelas. Maka dibuatkan perbaikan tampilan baru dengan merubah warna tampilan dengan perpaduan warna biru dan putih serta perbaikan menu tampilan pilihan untuk login, lupa password, menu untuk login lewat facebook dan menu buat akun baru yang dapat membuat user akan lebih paham dalam menggunakan aplikasi iBadung.

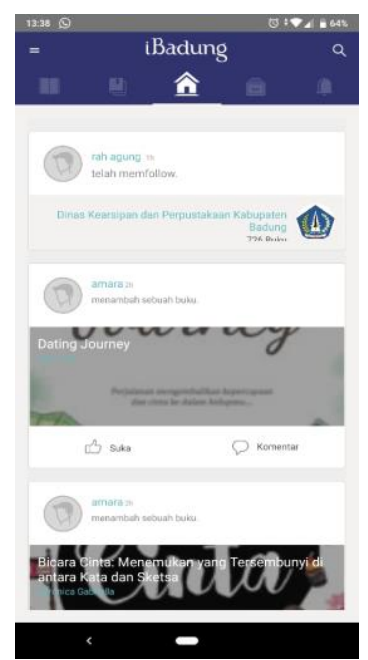

A

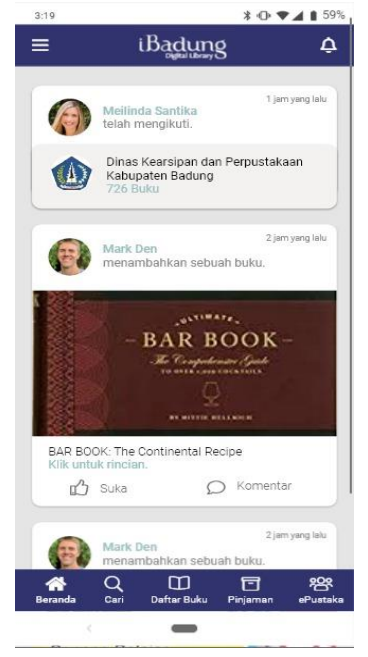

B

Gambar 4. Tampilan Menu Home

Gambar A merupakan tampilan menu home pada aplikasi iBadung sebelum dilakukan tahapan perbaikan tampilan, sedangkan gambar B telah dilakukan perbaikan sesuai dengan rekomendasi user hasil kuesioner pada aspek visibility of system status dan aspek consistency and standard yaitu bentuk icon harus sesuai dengan isi menu, nama menu, serta tata letak icon harus disesuaikan. Oleh karena itu perlu dilakukan perbaikan tampilan terhadap tata letak 
menu untuk dirubah dan diletakkan pada bagian bawah dan penambahan keterangan nama pada setiap menu, sedangkan icon menu home diletakkan di bagian paling kiri halaman dengan mengubah nama menu home yang semula bernama iBadung menjadi beranda. Menu ePustaka berubah letak posisi menjadi di pojok kanan bawah. Menu search sebelumnya berada pada pojok kanan atas menjadi masuk ke tengah menu utama serta menu notification yang sebelumnya ada pada menu utama berubah posisi letak pada pojok kanan atas.

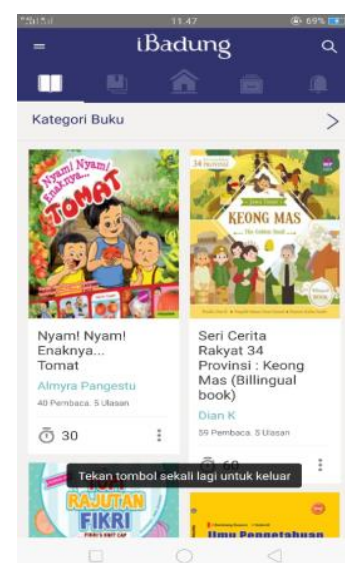

A

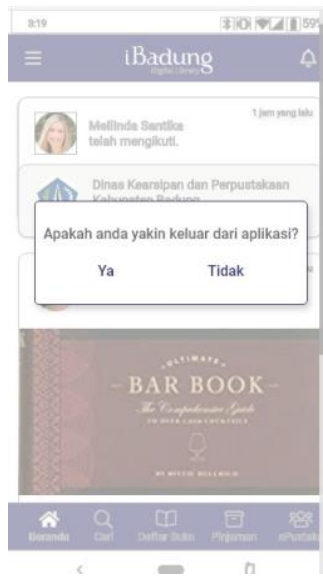

B

Gambar 5. Pop Up Exit Aplikasi iBadung

Gambar A merupakan tampilan pop up exit pada aplikasi iBadung sebelum dilakukan tahapan perbaikan tampilan yang berisi pesan untuk klik tombol back pada handphone user jika ingin keluar dari aplikasi, sedangkan gambar B telah dilakukan perbaikan sesuai dengan rekomendasi user dari hasil kuesioner pada aspek user control and freedom untuk dibuatkan sebuah pop up konfirmasi jika user ingin keluar dari aplikasi iBadung seperti yang tertera pada pada gambar $\mathrm{B}$.

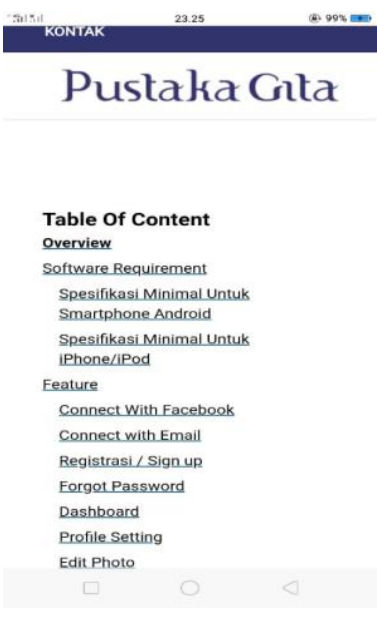

A

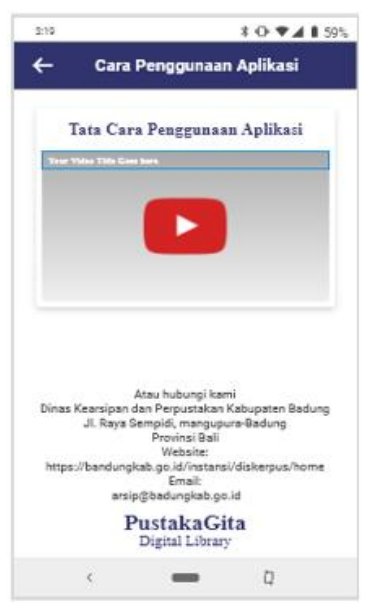

B

Gambar 6. Menu Tutorial Penggunaan Aplikasi

Gambar A merupakan tampilan menu tutorial penggunaan aplikasi iBadung sebelum dilakukan perbaikan tampilan, sedangkan gambar B telah dilakukan perbaikan tampilan sesuai dengan rekomendasi user dari hasil kuesioner pada aspek error prevention maka dibuatkan perbaikan tampilan baru dengan merubah pilihan konten dengan menyediakan video tutorial 
cara menggunakan aplikasi, karena dapat mempermudah user mempelajari cara menggunakan aplikasi tanpa takut akan terjadi kesalahan, dengan melihat video yang disediakan akan menjadi lebih mudah dibandingkan membaca seperti menu sebelumnya.

\subsection{Hasil Pengujian Usability Heuristic Evaluation Tahap Kedua}

Berikut merupakan hasil konfirmasi tahap kedua setelah perbaikan tampilan dilakukan. Pengujian ini ditunjukan kepada responden yang terlibat sebelumnya.

Tabel 5. Hasil Pengujian Pengguna Awam

\begin{tabular}{lcc}
\hline \multicolumn{1}{c}{ Aspek } & Nilai Masing-masing Aspek & Nilai Pembulatan \\
\hline 1. Visibility of system status & 1.057 & 1 \\
2. Match between system and the & 1.138 & 1 \\
real world & & \\
3. User control and freedom & 0.900 & 1 \\
4. Consistency and standard & 1.067 & 1 \\
5. Error prevention & 1.080 & 1 \\
6. Recognition rather than recall & 0.925 & 1 \\
7. Flexibility and efficiency of use & 0.767 & 1 \\
8. Aesthetic and minimalist design & 0.825 & 1 \\
9. Help users recognize, & 0.914 & 1 \\
diagnose, and recover from errors & & \\
10. Help and documentation & 0.880 & 1 \\
Nilai Rata-rata Severity Rating & 0.955 & 1 \\
\hline
\end{tabular}

Tabel 5 merupakan hasil konfirmasi perbaikan tampilan yang telah dilakukan berdasarkan rekomendasi user dari pengujian usability dengan metode Heuristic Evaluation dan mendapatkan hasil nilai severity rating dari masing-masing aspek. Nilai rata-rata severity rating yang diperoleh yaitu 0.955 yang dibulatkan menjadi skala 1 cosmetic problem.

Tabel 6. Hasil Pengujian Pengguna Biasa

\begin{tabular}{lcc}
\hline \multicolumn{1}{c}{ Aspek } & Nilai Masing-masing Aspek & Nilai Pembulatan \\
\hline 1. Visibility of system status & 0.943 & 1 \\
2. Match between system and the & 0.975 & 1 \\
real world & 1.400 & 1 \\
3. User control and freedom & 1.044 & 1 \\
4. Consistency and standard & 0.440 & 0 \\
5. Error prevention & 0.550 & 1 \\
6. Recognition rather than recall & 0.800 & 1 \\
7. Flexibility and efficiency of use & 0.850 & 1 \\
8. Aesthetic and minimalist design & 1.257 & 1 \\
9. Help users recognize, & & 1 \\
diagnose, and recover from errors & 1.120 & 1 \\
10. Help and documentation & 0.938 & 1 \\
Nilai Rata-rata Severity Rating & & \\
\hline
\end{tabular}

Tabel 6 merupakan hasil konfirmasi perbaikan tampilan yang telah dilakukan berdasarkan rekomendasi user dari pengujian usability dengan metode Heuristic Evaluation dan mendapatkan hasil nilai severity rating dari masing-masing aspek. Nilai rata-rata severity rating yang diperoleh yaitu 0.938 yang dibulatkan menjadi skala 1 cosmetic problem. 
Tabel 7. Hasil Pengujian Pengguna Administrator

\begin{tabular}{lcc}
\hline \multicolumn{1}{c}{ Aspek } & $\begin{array}{c}\text { Nilai SR Masing-Masing } \\
\text { Aspek }\end{array}$ & Nilai Pembulatan \\
\hline 1. Visibility of system status & 0.3 & 0 \\
2. Match between system and the & 0.3 & 0 \\
real world & 0.0 & 0 \\
3. User control and freedom & 0.0 & 0 \\
4. Consistency and standard & 0.1 & 0 \\
5. Error prevention & 0.4 & 0 \\
6. Recognition rather than recall & 0.2 & 0 \\
7. Flexibility and efficiency of use & 0.0 & 0 \\
8. Aesthetic and minimalist design & 0.8 & 1 \\
9. Help users recognize, diagnose, & 1.3 & 1 \\
and recover from errors & 0.3 & 0 \\
10. Help and documentation & & \\
Nilai rata-rata severity rating & & \\
\hline
\end{tabular}

Tabel 7 merupakan hasil konfirmasi perbaikan tampilan pengujian oleh administrator dengan metode Heuristic Evaluation dan mendapatkan hasil nilai severity rating dari masingmasing aspek. Nilai rata-rata severity rating yang diperoleh setelah perbaikan design yaitu 0.3 yang dibulatkan menjadi skala 0 , artinya tidak ditemukan adanya permasalahan lagi pada usability tersebut.

\section{Kesimpulan}

Hasil pengujian pertama dengan metode Heuristic Evaluation berdasarkan responden pengguna awam mendapatkan nilai rata-rata severity rating pada skala 2 yang berarti perbaikan prioritas rendah tetapi perbaikan tetap dilakukan. Responden pengguna biasa mendapatkan hasil skala 1 cosmetic problem perbaikan dapat dilakukan jika waktu proyek masih tersedia. Responden pengguna administrator mendapat hasil skala 1 cosmetic problem perbaikan dapat dilakukan jika waktu proyek masih tersedia. Beberapa perbaikan design interface yang perlu dilakukan yaitu pada aspek yang memiliki nilai severity rating skala 2 pada hasil pengujian pengguna awam yaitu pada aspek $\mathrm{H} 1$ Visibility Of System Status, H2 Match Between System And The Real World, H4 Consistency And Standard, H5 Error Prevention. Pengujian kedua setelah perbaikan tampilan dengan metode heuristic evaluation responden pengguna awam mendapat severity rating skala 1. Responden pengguna biasa mendapat severity rating skala 1 . Responden Administrator mendapat severity rating 0 . Perbandingan nilai yang didapat dari pengujian pertama dan kedua yaitu mendapatkan perubahan nilai severity rating yang lebih baik pada pengujian kedua.

\section{Daftar Pustaka}

[1] A. I. G. Prakasa and F. Ardiansyah, "Perancangan User Experience Aplikasi Marketplace Paket Wisata Indonesia untuk Wisatawan Lokal," J. IImu Komput. dan AgriInformatika, 2018, doi: 10.29244/jika.5.1.51-60.

[2] L. Hardiansyah and K. Iskandar, "Perancangan User Experience Website Profil Dengan Metode The Five Planes (Studi kasus: BP3K Kecamatan Mundu)," J. IIm. INTECH (Information Technol. Journal) UMUS, 2019.

[3] D. A. P. A. Widhiani, I. K. R. Arthana, and I. M. A. Pradnyana, "Analisa User Experience Pada Sistem Informasi Akademik Universitas Pendidikan Ganesha Ditinjau dari Pengguna Mahasiswa," J. Pendidik. Teknol. dan Kejuru., 2018, doi: 10.23887/jptkundiksha.v15i1.13048.

[4] V. Intanny, I. Widiyastuti, M. Dolorosa, and K. Perdani, "Pengukuran Kebergunaan dan Pengalaman Pengguna Marketplace Jogjaplaza . id dengan Metode UEQ dan USE Questionnaire," Pekommas, 2018.

[5] A. Kurniawan, R. I. Rokhmawati, and A. Rachmadi, "Evaluasi User Experience dengan 
Metode Heuristic Evaluation dan Persona (Studi pada: Situs Web Dalang Ki Purbo Asmoro)," J. Pengemb. Teknol. Inf. dan IImu Komput., 2018.

[6] M. L. Khakim, O. O. Sharif, S. Prodi, M. Bisnis, F. Ekonomi, and U. Telkom, "Analisis User Experience Aplikasi Go-Jek Menggunakan Heart Metrics," e-Proceeding Manag., 2018.

[7] R. Firmansyah, "Usability Testing Dengan Use Questionnaire Pada Aplikasi Sipolin Provinsi Jawa Barat," Swabumi, vol. 6, no. 1, pp. 1-7, 2018, doi: 10.31294/swabumi.v6i1.3310.

[8] M. S. Hartawan, "Analisa User Interface Untuk Meningkatkan User Experience Menggunakan Usability Testing Pada Aplikasi Android Pemesanan Test Drive Mobil," J. Teknol. Inf. ESIT Vol. XIV, 2019.

[9] R. F. A. Aziza, "ANALISA USABILITY DESAIN USER INTERFACE PADA WEBSITE TOKOPEDIA MENGGUNAKAN METODE HEURISTICS EVALUATION," J. Tekno Kompak, 2019, doi: 10.33365/jtk.v13i1.265.

[10] A. Setiawati, A. Rahim, and D. Kisbianty, "Pengembangan dan Pengujian Aspek Usability pada Sistem Informasi Perpustakaan ( Studi Kasus: STIKOM Dinamika Bangsa Jambi )," Processor, 2018.

[11] L. D. Farida, "Pengukuran User Experience Dengan Pendekatan Usability [Kasus: Website Pariwisata Di Asia Tenggara]," Semin. Nas. Teknol. Inf. dan Multimed., 2016.

[12] B. A. Mustikaningtyas, M. C. Saputra, and A. Pinandito, "Analisis Usability Pada Website Universitas Brawijaya Dengan Heuristic Evaluation," J. Teknol. Inf. dan IImu Komput., 2016, doi: 10.25126/jtiik.201633194.

[13] O. B. KHUAN, "STUDY OF FSKKP PORTAL BASED ON SHNEIDERMAN"S EIGHT GOLDEN RULES," J. Teknol., 2013, doi: 10.11113/jt.v56.60. 